\title{
El ensayo y la experiencia americana ${ }^{1}$
}

Octubre 2020

\author{
Liliana Weinberg* \\ "Nuestro mundo acaba de encontrar otro" \\ Michel de Montaigne, Ensayos, III, VI
}

\section{El ensayo del nuevo mundo}

Existe una estrecha relación entre el nuevo mundo del ensayo y el ensayo del nuevo mundo. Como ya lo dijo Germán Arciniegas en 1963, "Nuestra América es un ensayo": “América surge en el mundo, con su geografía y sus hombres, como un problema. Es una novedad insospechada que rompe con las ideas tradicionales. América es ya, en sí, un problema, un ensayo de nuevo mundo, algo que tienta, provoca, desafía a la inteligencia". 2 De este modo, Arciniegas considera no sólo que la prosa de ideas ha tenido un desarrollo excepcional en nuestra región desde el siglo XVI, sino también que la propia historia americana es un ensayo de nuevo mundo y que América emerge a la conciencia europea como un problema dado a la reflexión, desafiando las viejas certezas sobre el mundo conocido. Para decirlo con palabras de hoy, desde el reordenamiento de la historia que sugiere el giro descolonial (de Aníbal Quijano a Rita Segato), antes de América Europa no existía. La presencia de América contribuye a la reorganización del mundo y a la generación de una nueva episteme. Se da un reordenamiento de la historia a partir del ingreso de la idea de futuro y la idea de horizonte, e incluso el concepto de raza se inventa

\footnotetext{
1 Texto ampliado de la conferencia impartida en el XXV Coloquio de Investigación "Conocer América Latina y el Caribe”, organizado por el CIALC, UNAM, en el marco de los 40 años de su creación. Este texto retoma además ideas adelantadas en El ensayo en busca del sentido, México-Madrid-Berlín: CIALC-IberoamericanaVervuert, 2014.

* Liliana Weinberg es ensayista, crítica literaria, investigadora y editora en el campo de la literatura en su relación con la cultura, la tradición literaria, las ideas estéticas y la historia intelectual. A lo largo de su carrera se ha especializado en la teoría y crítica del ensayo en general, y se ha orientado en particular al estudio del ensayo hispanoamericano de los siglos XIX y XX. Es autora de libros dedicados al ensayo así como de numerosos trabajos sobre la obra de algunos de sus principales representantes, temas y problemas. 2 Germán Arciniegas, "Nuestra América es un ensayo”, Cuadernos (París), 3 (1963), pp. 9-16.
}

Revista Moara, n. 56, vol. 1, ago-dez 2020 ISSN:0104-0944 
allí. Quijano es muy radical al decir que lo colonial precede a lo moderno, no hay modernidad posible sin lo colonial. El ensayo ha sido testigo de este reordenamiento de la historia, con la instalación de la idea de futuro y la apertura a la idea de horizonte y de este reordenamiento de los géneros a partir de la tematización de lo americano y el surgimiento de una nueva concepción de la subjetividad. Como ha dicho Rita Segato, sólo la reserva de valor y legitimidad se transfiere de pasado a futuro con el evento americano, se instala la idea de futuro y también una nueva concepción de la subjetividad. Es así como asistimos a la precedencia de la colonialidad para hacer posible el camino de la modernidad y la nueva forma de la historia. Varias cosas nacen al mismo tiempo: España, Europa, América, el blanco, el negro, el indio. Es en ese mismo momento, en esa especie de "magma originario", cuando emerge un nuevo orden del mundo y emerge un nuevo género: el ensayo. No debemos olvidar que la prédica de Bartolomé de Las Casas es también un precedente fundamental del género, en cuanto su crítica de la voracidad de los conquistadores lo conduce a una temprana y valiente toma de distancia respecto de su propia cultura y a una defensa de la cultura indígena.

La necesidad de tematizar la realidad americana implicará a su vez toda una sacudida en el sistema de la prosa no ficcional, ya que estos nacientes ensayos deben ahora entrar en diálogo con innumerables modalidades discursivas, como las cartas, las crónicas, los relatos de viaje, así como también con un innumerable arsenal de formas jurídicas: ordenanzas, probanzas, actas, testamentos, en un espacio saturado por el discurso jurídico.

Regresando a Arciniegas, coincido plenamente con su afirmación, ya que es innegable la importancia que ha tenido y sigue teniendo la producción ensayística en América Latina: una forma de la prosa no ficcional que contribuyó a lo largo de los siglos para interpretar nuestra experiencia y dotarla de sentido. El ensayo, esa forma de la literatura de ideas, ese "ejercicio del estilo y del pensamiento que permite seguir los movimientos de la conciencia en la búsqueda de la verdad", ese "centauro de los géneros", "pensamiento situado, comprometido, responsable y con una dimensión política en casi todos los casos ...", ese género deliberativo interior y al mismo tiempo de apertura al mundo, ese ejercicio de lucidez para la interpretación de la propia relación con nuestra lengua y nuestra cultura, y que en la tradición latinoamericana confirma precisamente la

Revista Moara, n. 56, vol. 1, ago-dez 2020 ISSN:0104-0944 
naturaleza predominantemente cultural de su objeto. Yo añadiría a ello otro componente fundamental: el marcado elemento jurídico, la lucha por la legitimidad de la palabra, el problema de la representatividad de lo dicho, que hace que de algún modo América y el ensayo compartan destinos.

Sus primeros antecedentes pueden rastrearse ya, como lo vengo sosteniendo, hasta Fray Bartolomé de Las Casas, cuya obra resultó a su vez tan importante para reconfigurar la imagen que Europa tuvo del Nuevo Mundo, y que influyó incluso en el propio Miguel de Montaigne, padre del ensayo. En efecto, entre su ensayo "De los caníbales" y su ensayo "De los coches" hay un cambio radical de enfoque respecto del daño que la conquista europea estaba haciendo ya en América. Me interesa destacar que el gesto de Las Casas, el primer gesto de toma de distancia crítica respecto de la cultura de conquista a la que él mismo pertenecía, aunado a la actitud crítica de Montaigne, una de las primeras posturas anticolonialistas de la historia, dotarán de un rasgo particular al ensayo, decisivo para nuestra región, ya que una de las líneas del ensayo, que apunta a lo político e ideológico, muestra un fuerte vínculo con el discurso jurídico.

Es interesante descubrir que, tras un primer momento de "tupinambización"3 de su mirada, en que reflexiona sobre los caníbales a partir de las tempranas noticias procedentes de los primeros franceses que arribaron a las costas de América, Montaigne da cuenta de las noticias que llegan sobre el descubrimiento de los mundos azteca e inca, tal como consta en "De los coches". Vincula las noticias de América con sus propias reflexiones sobre la verdad, la cercanía con la naturaleza, e incluso el tema americano, que aparece nada más y nada menos que desde el aviso al lector: "Que si hubiera yo estado en esas naciones que se dice que viven todavía en la dulce libertad de las primeras leyes de la naturaleza, te aseguro que gustosamente me hubiese pintado de cuerpo entero y totalmente desnudo".

Eximios ensayistas como Pedro Henríquez Ureña y Alfonso Reyes fueron ampliamente conscientes de la importancia y el eco que tuvieron las reflexiones de Montaigne sobre la realidad americana para el reconocimiento de la especificidad de nuestro continente y de su “mayoría de edad”. Así lo muestran las páginas donde Pedro

3Término empleado por F. Lestringant en la entrada correspondiente a "Mexique-Pérou", Dictionnarie de Michel de Montaigne

Revista Moara, n. 56, vol. 1, ago-dez 2020 ISSN:0104-0944 
Henríquez Ureña se refiere a la discusión en torno al tema de los indígenas en distintos lugares de Europa. Con su consabida lucidez anota:

La discusión alcanza su mayor altura con Montaigne, en dos ensayos famosos -uno sobre los caníbales, el otro sobre los carruajes- y en muchas observaciones dispersas. Montaigne llevó la crítica de la civilización europea, en comparación con el estado salvaje, a sus consecuencias extremas. Había leído unas cuantas crónicas de viajes y conquistas; además, había conversado con viajeros, marineros, mercaderes, y aun con salvajes brasileños llevados a Rouen durante el reinado de Carlos IX. ${ }^{4}$

Descubre acertadamente Henríquez Ureña que el autor francés "condena, con el mismo espíritu de Las Casas, la invasión europea [...] y comprende -como muy pocos europeos en su tiempo- que había grandes civilizaciones en América cuando llegaron los españoles". 5

A estas reflexiones pueden añadirse las de Alfonso Reyes, quien se preocupa por el tema americano y la utopía de América, recuperando lo que significó el descubrimiento, el pensamiento humanista y ese "exotismo americano" cargado de una intención política y moral. Reyes ve en Montaigne uno de "los más nobles maestros del pensamiento europeo" que pide "al Nuevo Mundo un estímulo para el perfeccionamiento político de los pueblos":

El testimonio de Montaigne es singularmente expresivo. En su alma se da el drama del Descubrimiento envuelto en aquella clara música de ideas que todavía nos conmueve. Montaigne reconoce que el solo contraste entre el Antiguo y el Nuevo Mundo lo despertó a esa comprensión para todas las doctrinas que Bacon y Shakespeare aprenderán de él [...]. Durante la juventud de Montaigne, América se iba ensanchando día por día, y la creciente gravitación de América parece irlo levantando sobre el nivel moral de su tiempo. ${ }^{6}$

Ved cómo, a medida que se agranda América, se alza Montaigne, a un nivel más alto para dominar el panorama de razas y civilizaciones. Ved cómo la sola aparición de América parece fertilizar la mente de los más agudos pensadores.?

4 Pedro Henríquez Ureña, "El descubrimiento del Nuevo Mundo en la imaginación de Europa", en Las corrientes literarias en la América Hispánica, Obras Completas, t. X, Santo Domingo: UNPHU, 1980, p. 63. 5 Ibid., p. 65.

6 Alfonso Reyes, Última Tule, en Obras Completas, t. XI, México: FCE, 1960, p. 58-59.

7 Ibid., p. 73.

Revista Moara, n. 56, vol. 1, ago-dez 2020 ISSN:0104-0944 
Es así como es posible explorar el vínculo de esta nueva clase de textos con las repercusiones que tuvo el descubrimiento del mundo americano para la mentalidad europea. Las novedades americanas se cuelan en la obra de Montaigne, quien responde con curiosidad y con indignación a los avances de la conquista de América. El propio humanismo de Montaigne se pone a prueba cuando su horizonte se amplía de tan extraordinaria manera. A partir de entonces quedará impresa como "marca de agua" del género su voluntad de entender, interpretar, someter a crítica las propias certezas, ejercitar el asombro y la capacidad de inscribir la propia experiencia en un horizonte más amplio de sentido: nombrar, relacionar, dotar de inteligibilidad el mundo, la vida. Desde la mirada crítica de Montaigne hasta la postura francamente colonialista de Bacon, mucho debe esta nueva clase de textos a las repercusiones que tuvo el descubrimiento del orbe americano para la mentalidad europea.

\section{El nuevo mundo del ensayo}

Podemos hablar entonces de un ensayo del nuevo mundo como podemos hablar del nuevo mundo del ensayo, ya que, en efecto, el ensayo americano no se nutre sólo pasivamente de modelos europeos, sino que va adquiriendo una personalidad propia, que "hace familia" además con una gran cantidad de formas de la prosa que van surgiendo a partir de la experiencia americana, desde las crónicas y las cartas hasta los testimonios de las órdenes que llegan a América.

Y ya en los siglos posteriores nuestro continente habrá de incorporar y reinterpretar distintas "oleadas" de ensayo. La "Respuesta a Sor Filotea" de Sor Juana, fechada el 1 de marzo de 1692 en México, en su defensa de la curiosidad intelectual y el derecho a defender la propia experiencia, tiene rasgos cercanos al ensayo.

Pues ¿qué os pudiera contar, Señora, de los secretos naturales que he descubierto estando guisando? Veo que un huevo se une y fríe en la manteca o aceite y, por contrario, se despedaza en el almíbar; ver que para que el azúcar se conserve fluida basta echarle una muy

Revista Moara, n. 56, vol. 1, ago-dez 2020 ISSN:0104-0944 
mínima parte de agua en que haya estado membrillo u otra fruta agria; ver que la yema y clara de un mismo huevo son tan contrarias, que en los unos, que sirven para el azúcar, sirve cada una de por sí y juntos no. Por no cansaros con tales frialdades, que sólo refiero por daros entera noticia de mi natural y creo que os causará risa; pero, señora, ¿qué podemos saber las mujeres sino filosofías de cocina? Bien dijo Lupercio Leonardo, que bien se puede filosofar y aderezar la cena. Y yo suelo decir viendo estas cosillas: Si Aristóteles hubiera guisado, mucho más hubiera escrito $[\ldots]$.

Confieso también que con ser esto verdad tal que, como he dicho, no necesitaba de ejemplares, con todo no me han dejado de ayudar los muchos que he leído, así en divinas como en humanas letras. Porque veo a una Débora dando leyes, así en lo militar como en lo político, y gobernando el pueblo donde había tantos varones doctos. Veo una sapientísima reina de Saba, tan docta que se atreve a tentar con enigmas la sabiduría del mayor de los sabios, sin ser por ello reprendida, antes por ello será juez de los incrédulos. Veo tantas y tan insignes mujeres: unas adornadas del don de profecía, como una Abigaíl; otras de persuasión, como Ester; otras, de piedad, como Rahab; otras de perseverancia, como Ana, madre de Samuel; y otras infinitas, en otras especies de prendas y virtudes... pues todas no fueron más que mujeres doctas, tenidas y celebradas y también veneradas de la antigüedad por tales. Sin otras infinitas, de que están los libros llenos, pues veo aquella egipcíaca Catarina, leyendo y convenciendo todas las sabidurías de los sabios de Egipto. Veo una Gertrudis leer, escribir y enseñar. Y para no buscar ejemplos fuera de casa, veo una santísima madre mía, Paula, docta en las lenguas hebrea, griega y latina y aptísima para interpretar las Escrituras. ${ }^{8}$

8 Sor Juana Inés de la Cruz, Respuesta a Sor Filotea, México: Editores Mexicanos Unidos, 2001 [1575].

Revista Moara, n. 56, vol. 1, ago-dez 2020 ISSN:0104-0944 
En el siglo XVIII la prosa se abre al espíritu de experimentación propio de la herencia del ensayo inglés, además de la prosa de un creciente número de viajeros y científicos, como Humboldt. Los jesuitas expulsos serán algunos de los primeros en escribir "Ensayos" propiamente dichos, como es el caso del Saggio sulla Storia Naturale del Chili (1782), del Juan Ignacio Molina, hoy mencionado en páginas como la Biodiversity Heritage Library. "La atención de la Europa se ha vuelto preferentemente hacia América: se busca con curiosidad erudita conocer la diversidad de sus climas, la estructura de sus montañas, la naturaleza de sus fósiles, la forma de sus vegetales y animales, los caracteres, las costumbres y las lenguas de sus habitantes...". Llama a Chile, con la nostalgia del exiliado, "el jardín de la América meridional".

Fundamental es también la expansión de la atmósfera ilustrada para la inclusión de las ideas de razón, experiencia y exploración. Desde fines del siglo XVIII despunta también el ensayo ligado al periodismo, que le imprime un nuevo ritmo, un nuevo estilo, un nuevo formato a la prosa. El género se renueva en todos sus alcances políticos a partir de los grandes ensayos de la Ilustración y de la Revolución Francesa: a inspiración de Voltaire se decantará por un enfoque ligado al examen crítico de las costumbres y a inspiración de Rousseau a la deliberación interior. Mientras que el ensayo del cristianismo ilustrado en la estela de Feijoo se va abriendo paso en las bibliotecas, muchos de los textos procedentes de Francia y las trece colonias ingresarán como "ideas de contrabando" perseguidas por el régimen colonial, y pronto el reclamo de la libertad de prensa y expresión se convertirá en una de las demandas fundamentales de la prosa de ideas en la región. Precisamente el primer ensayo político americano, de Bernardo de Monteagudo, estará organizado como un recuento de las grandes etapas que habría de atravesar América, de la esclavitud a la libertad.

Es así como, sobre todo a partir de la etapa de la independencia, nuestros más grandes escritores e intelectuales se fueron apropiando de un género al que dotaron de nuevos alcances reflexivos, éticos y estéticos, con el objeto de hacer inteligible su mundo y a la vez poner en diálogo la propia realidad con las condiciones de inteligibilidad

9 Juan Ignacio Molina, Saggio sulla Storia Naturale del Chili, Bolonia: Stamperia di San Tommaso d'Aquino, 1782, p. 3. Disponible en: https://bivaldi.gva.es/es/consulta/registro.cmd?id=6582

Revista Moara, n. 56, vol. 1, ago-dez 2020 ISSN:0104-0944 
imperantes. Se trataba además de hacer de la lengua de conquista una lengua de contraconquista. La misma lengua española que explora el ensayo será pronto juzgada como lengua heredada de los conquistadores.

El ensayo surge ligado a la reflexión, a la exploración, a la defensa de la experiencia, a la apertura de horizontes, al viaje intelectual. De este modo, la pulsión crítica y autocrítica del ensayo, su capacidad para mediar entre tiempos y espacios, culturas y lenguas, experiencias concretas y búsqueda de horizontes universales, es una marca de origen. Desde el ensayo literario propiamente dicho, que reúne creación y crítica, lectura y escritura, que explora las potencialidades de la lengua en busca de "una palabra garante de su decir", ${ }^{10}$ hasta el ensayo que transita en los territorios de la historia, la sociedad, la cultura, el debate político e ideológico, los autores latinoamericanos han hecho aportes sustanciales al género. El ensayo permitió precisamente vincular la situación concreta, el tiempo presente, el yo-aquí-ahora, con la búsqueda de sentido, en un paso del yo al nosotros, y en un paso, además, que busca, si no lo universal, la universalización.

En América se reorientan los puntos cardinales del ensayo: por una parte, se abre la posibilidad de escribir ensayo de corte personal, subjetivo, autobiográfico, en la línea de Montaigne, así como de llevar al ensayo a altas cotas de experimentación estética, explorando nuevos espacios como la autoficción, la memoria, siempre en diálogo con la palabra, el lenguaje, la lectura, la escritura. Porque el ensayo es transitivo e intransitivo: habla del mundo y habla de su propia forma. Por la otra, se abre la posibilidad de dedicarse al ensayo de corte ideológico, histórico y de crítica cultural; muchos son hoy quienes se preocupan por explorar, profundizar, someter a crítica, la forma ensayo en sí misma y muchos son también quienes buscaron entretejerla con la narrativa, la lírica, la representación del acto mismo de pensar, sentir, entender el mundo.

Como bien ha afirmado Arturo Andrés Roig, "los orígenes históricos inmediatos del ensayo latinoamericano se encuentran en la praxis política entendida, asimismo, como ensayo y es desde ésta que se proyectó al campo de las letras". Y recuerda las palabras de Simón Rodríguez, maestro del Libertador, a Simón Bolívar el 7 de enero de 1825, cuando

10 Jean-Pierre Zubiate, "Essai et poésie au XXè siècle", en Pierre Glaudes, L'Essai. Métamorphoses d'un genre, Université de Toulouse-le-Mirail: Presses Universitaires du Mirail, 2002.

Revista Moara, n. 56, vol. 1, ago-dez 2020 ISSN:0104-0944 
consideraba al nuevo mundo "el lugar propio... para los ensayos". 11 Roig ha mostrado certeramente la transformación que sufre el ensayo en el siglo XIX, ligado a la búsqueda de una emancipación mental del americano, y los efectos de la lectura romántica, "que generó un ensayo en el que como momento necesario se debían incorporar todos los aspectos de una realidad vista como fundamentalmente conflictiva". ${ }^{12}$

Por otra parte, si algo caracteriza al ensayo en lengua española es que, como ha dicho Jean Marcel, la individualidad parece no poder comprenderse a sí misma sino a través de su inserción en la serie histórica y cultural que la ha producido, ya que el ensayista edifica su discurso a partir del dato cultural, que constituye la mediación privilegiada por la cual el yo intenta recuperar su ser fragmentado y mediación que crea una intimidad del sujeto con su objeto. ${ }^{13}$

El ensayo, género paradójico si los hay, se balancea entre entendedores y sentidores, puesto que, como dijo García Márquez, al término intelectuales debemos completarlo con otro término, el de los "sentimentales", los artistas... El ensayo ha sido así permanente fuente de alimentación entre lectura y escritura, crítica y creación, ha sido construcción de bibliotecas simbólicas y renovador de tradiciones de pensamiento. El ensayo ha representado un modo literario del conocer. El ensayo ha contribuido además a explorar las paradojas en la relación de nuestra región con el pensamiento europeo y el de otras partes del mundo.

Muchas y muy notables son las contribuciones que los escritores de este Nuevo Mundo hicieron a la renovación de la prosa. América regresó al viejo mundo, a partir de la obra de genios como Las Casas, Simón Rodríguez, Simón Bolívar, Andrés Bello, Domingo Faustino Sarmiento, José Martí, que aportaron una renovación del pensamiento político y jurídico. Más aún, que fueron forjando una nueva idea de lo americano y una renovación de la prosa. Recordemos la potencia de las palabras de Martí en "Nuestra América": "la prosa,

11 Arturo Andrés Roig, "Educación para la integración y utopía en el pensamiento de Simón Rodríguez. Romanticismo y reforma pedagógica en América Latina", Latinoamérica. Anuario de Estudios Latinoamericanos, núm. 15, 1982, p. 340.

12 Ibid., p. 342.

13 Jean Marcel, "Forme et fonction de l'essai dans la littérature espagnole”, pp. 99-100.

Revista Moara, n. 56, vol. 1, ago-dez 2020 ISSN:0104-0944 
centelleante y cernida, va cargada de idea". ${ }^{14}$ A partir de Darío, Reyes, Lezama, Martínez Estrada, Borges, Paz, Fuentes, entre tantos otros nombres notables, el ensayo significó una renovación de la relación entre creación, crítica, inteligencia.

Es innegable la importancia que ha tenido y sigue teniendo la producción ensayística en América Latina. Nuestros intelectuales lograron inscribir en el ensayo un estilo del pensar y el traducir la vida americana. Hoy vivimos nuevos tiempos, entre otras cosas caracterizados, como afirma de manera luminosa Chakrabarty, por una provincialización de otras partes del globo. Y de este modo, una vez más, debemos ensayarnos y continuar construyendo nuestra propia tradición intelectual, nuestras eras imaginarias.

Me atrevería a decir que todas las grandes líneas del ensayo confluyen en José Martí, escritor y político, poeta y prosista, cronista y periodista, quien labró desde la alta prosa, centelleante y cernida, cargada de idea, como él mismo lo dijo, un nuevo espacio identitario al que llamó Nuestra América. Martí periodista, cronista, político, renovador del pensamiento, creador, crítico de arte y literatura, verdadero trabajador intelectual, en un momento de modernización en que se da una tensión entre el Libro con mayúsculas y la práctica periodística, entre la lectura para pocos y la lectura para muchos, hizo confluir todas estas líneas y las resolvió genialmente a través del ensayo. En efecto, su preocupación política y militante se resolvió también simbólicamente a través de la literatura de ideas.

¿En qué consiste, entonces, ese nuevo mundo del ensayo? En un cambio fundamental en la relación entre el autor, la obra, el lector, la tradición, las lecturas, el lenguaje, el conocimiento, la memoria, la vida. Un ejercicio de reflexión, un ejercicio de lucidez, que un autor entabla a partir de la observación de la propia experiencia y las propias lecturas, que organiza a través de la escritura del mundo y comparte con sus lectores, guiado por la fidelidad a la verdad y la autenticidad y la responsabilidad por sus palabras. Para que exista ensayo debe existir una postura crítica, una toma de distancia entre el autor y la realidad a nombrar, a indagar. El ensayo representa además un ejercicio de estilo en el pensar y en el decir, una forma literaria de conocer el mundo, una forma

14 José Martí, "Nuestra América”, en Obras Completas, t. VI, La Habana: Editorial de Ciencias Sociales, 1992 [1891], p. 21.

Revista Moara, n. 56, vol. 1, ago-dez 2020 ISSN:0104-0944 
estética de superar y resolver las contradicciones que otras modalidades de conocimiento no alcanzan a resolver. El ensayo hace pensable, nombrable, dota de inteligibilidad, la inmensa realidad social que nos rodea. Hume se consideraba un embajador del país del saber en el país de la conversación. La socialización del discurso de las ideas ha sido también fundamental en nuestro ámbito cultural, donde a través del diálogo, la polémica, se fue construyendo el espacio público.

\section{Hoy}

A lo largo del siglo XX, el ensayo alcanza su normalización como género en nuestra América, y es interesante porque florece tanto en el campo literario como en el campo intelectual, y muchas veces en la intersección entre ambas esferas, como es el caso ya mencionado de Martí, Reyes y Henríquez Ureña. En varias ocasiones me he dedicado a aquello que llamé "El ensayo en tierra firme", esto es, al proyecto impulsado por Daniel Cosío Villegas, director del Fondo de Cultura Económica, y por Alfonso Reyes, el gran hombre de letras mexicano, que hizo del ensayo el género maestro para la comprensión del mundo americano y que incluyó la presencia de autores brasileños.

El ensayo florece tanto en el campo de la creación como en el de la crítica, en el diálogo y en el debate, acompañando la consolidación de la que el propio Reyes llamó “inteligencia americana”. Movido entre la vocación de tierra firme y la vocación insular, conforme la literatura se abrió al mar, a las islas y los archipiélagos, comenzaron a fluir nuevas y magníficas muestras de la que llamé una "geopoética del Caribe", con ejemplos como los de Aimé Césaire, Léopold Senghor, Derek Walcott, Édouard Glissant, que dotaron al ensayo de nuevas audacias, de nuevas miradas radicales.

Género plástico, incluyente, sorprendente, crítico y autocrítico si los hay, el ensayo ha continuado, a través del ejercicio de la imaginación creadora, asomándose de manera cada vez más audaz a territorios, fronteras, abismos, y se ha puesto en diálogo con otras formas como la crónica, el testimonio, la biografía, el discurso de las ciencias sociales, el discurso académico o las nuevas oleadas de reflexión política y cultural. También descubrimos hoy complejísimos cruces entre ensayo y narrativa, entre ensayo y poesía,

Revista Moara, n. 56, vol. 1, ago-dez 2020 ISSN:0104-0944 
entre ensayo y crónica. El ensayo atraviesa también los desafíos de la migración entre distintos soportes y se liga hoy a otras formas como el cine.

Quizá el ensayo sea el género más apropiado para hablar de la realidad cambiante de nuestro continente, más aún, para ir configurando a través del discurso, el propio concepto, la propia imagen, de América Latina. Al fuerte fenómeno de las migraciones, que nos sacude a todos de nuestras certezas, y que hace pensar en la intemperie, la precariedad, la vulnerabilidad en que se encuentran tantos miles de seres humanos. Violencia y tráfico ilegal son también tema de reflexión. Hace ya más de veinte años Gabriel García Márquez decía "Mi impresión es que el tráfico de drogas es un problema que se le salió de las manos a la humanidad". ${ }^{15}$ El ensayo se asoma al tema de la ciudad, al miedo, al dolor, como se asoma también a la vida, a la memoria, a la experiencia de los cuerpos en el paisaje cultural.

Desde luego que el ensayo literario, con su prodigioso trabajo de la lengua, ha dado grandes aportes a la región. Y desde luego que muchos de nuestros mejores ensayistas son capaces también de abordar autocríticamente su lugar, su mirada. Pienso, para tomar un solo ejemplo, en un fuerte tironeo de luces y sombras como el que expresa el ensayista colombiano Pablo Montoya, en su diálogo con la lengua castellana, escrito en 2016:

Español, amantísima lengua que hablo desde niño y que hablaré cuando esté muriendo [...]. Español, lengua en la que creo que soy y sueño lo que soy y anhelo lo que tal vez nunca sea [...]. Estoy aquí para festejar tu existencia que me da cobijo, me arrulla y también me sobrecoge $[\ldots]$.

Yo vengo de ti. Soy hijo tuyo sabiendo que en mí te vuelves mi heredera. Soy parte de esa historia cuyas orillas siempre han sido el orgullo y la deshonra, la belleza y la fealdad, el heroísmo y la picardía, el amor y el odio de tantas generaciones que han atravesado esta ilusión del tiempo que todavía nos sostiene. Historia iniciada, acaso, en alguna aldea castellana [...]. Y entonces llegaste a América [...]. Pasaste, arrasadora, por estos lares americanos. Al lado de la cruz y la espada tu presencia se hizo tan imponente como abrumadora [...]. Las otras lenguas, habladas por los indios nativos y los negros provenientes de África, fueron prohibidas, ignoradas,

15 Gabriel García Márquez, "América Latina existe", El País (Madrid), 23 de octubre de 2010 [1995]. Disponible en: https://elpais.com/diario/2010/10/23/babelia/1287792762 850215.html

Revista Moara, n. 56, vol. 1, ago-dez 2020 ISSN:0104-0944 
muchas de ellas aniquiladas. Y el desprecio y el olvido cayeron sobre casi todas como una afrenta. Y tú nos enseñaste, durante siglos, que esas lenguas no eran tales, sino hablas sin importancia, frágiles expresiones de la barbarie, dialectos que conducían al salvajismo y la sandez. Toda una hermosa y original e inteligentísima expresión de la multiplicidad del mundo desapareció por tu prepotencia [...]. Con todo, tú eres un río colosal. Imparable y turbulento. Atribulado de rumores y gritos [...]. Cómo no celebrar ahora esa fuerza tuya, esa intimidad tuya y esos abrazos tuyos. Y de cuántas maneras yo quisiera hacerlo. ${ }^{16}$

He elegido este ejemplo porque permite ver cómo incluso desde el interior mismo del ensayo, desde la voz gozosa de un escritor que podría perfectamente estar en paz con una lengua que domina y lo domina, puede surgir una fuerte línea cuestionadora, crítica y autocrítica. Pero en los últimos años afortunadamente van ingresado nuevas voces, nuevas miradas, que amplían, enriquecen, complejizan la discusión.

Uno de los temas más fuertes que están surgiendo en los últimos tiempos es el de la relación del escritor con la lengua de escritura, sobre todo cuando los escritores provienen de ámbitos marginados y se ven obligados a escribir en una lengua segunda, esto es, no la lengua materna ni la segunda lengua, ya que, como escribe el africano Mwala Ngalasso, "Escribir en una lengua segunda es generalmente pensar en una lengua y escribir en otra". Algo particularmente fuerte si se piensa que existe un vínculo entre lengua, cultura y pensamiento y que la conciencia lingüística es la base de la conciencia cultural. Otro elemento fundamental es el ingreso de la oralidad, la dramatización, la performación, el ritmo, las voces... hoy, las voces de la protesta.

En las últimas décadas emerge el ensayo de autores que hablan de la experiencia indígena y afrodescendiente, que nos conmocionan como lo hace también el nuevo ensayo feminista, y ya empiezan a circular textos en prosa que nos hablan y que tratan de nombrar, de entender, de interpretar, el sacudón, la sorpresa, el dolor, la consternación ante los

16 Pablo Montoya, "Español, lengua mía”, en Español, lengua mía y otros discursos, Medellín: Sílaba Editores, 2017, pp. 9-21.

Revista Moara, n. 56, vol. 1, ago-dez 2020 ISSN:0104-0944 
movimientos que se viven hoy, literalmente hoy, en países como Chile, Bolivia, Colombia, Costa Rica, Nicaragua, que están haciendo temblar la columna vertebral andina de nuestra América.

Así, por ejemplo, si en el ensayo es tan ostensible la importancia del punto de vista, la mirada, la perspectiva, hoy el Ensayo sobre la ceguera de Saramago se ha convertido en símbolo para algunos cronistas de la brutal represión chilena: los carabineros hieren en sus ojos a los manifestantes: "Los quiero mirar a todos, con el único ojo que me queda", dice el estudiante Rodrigo Lagarini.

Mencionaré a Blas Jiménez (1949-2009), escritor dominicano y afrodescendiente, autor del texto titulado "Afrodominicano por elección/negro por nacimiento", quien escribe:

En esta isla, cuna del contexto latinoamericano tradicionalmente definido desde el imaginario eurocéntrico como "Sociedad Occidental", la realidad existencial de la gente de ascendencia africana tiende a ser fragmentada, dividida, rota, cascada, como el velo que cubre nuestra conciencia de ser.

En este código cultural unipolar/eurocéntrico, va mi identidad divergente obligándome a vivir en la doblez de ser una cosa hoy que no quiero ser mañana, como fui ayer lo que ya no quiero ser hoy.

Como afro/dominicano/negro vivo mundos diferentes y me debato, continuamente, entre un querer ser mi historia y un rechazar lo que me dicen fue esa historia; entre estar orgulloso de la cosmogonía heredada de mis ancestros, en un mundo de imágenes atrapadas en sueños y un querer ser la negación de lo que refleja el espejo...

Pero comprendo que si es cierto que nacemos en la historia, morimos fuera de ella. Reconozco que voy haciendo historia al vivir, lo que vivo es mi historia. El sentido de la historia es el que le damos, cada uno de nosotros, desde la vida. Somos nosotros y nosotras quienes forjando historias individuales damos sentido a la historia colectiva. ${ }^{17}$

Y ya que de mundos viejos y nuevos hemos venido hablando, cito para terminar un pasaje del ensayo de Yásnaya Aguilar Gil, escritora y activista mixe y una de las más interesantes ensayistas contemporáneas de México. Su título es "Sobre calabazas y chilacayotes. Lengua, palabras y visión del mundo":

17 Blas Jiménez, "Afrodominicano por elección/negro por nacimiento", en Afrodominicano por elección/negro por nacimiento, Santo Domingo: Manatí, 2008, pp. 9-10.

Revista Moara, n. 56, vol. 1, ago-dez 2020 ISSN:0104-0944 
Una de las frases más recurridas para explicar la importancia de la diversidad lingüística ha sido: "una lengua es una visión del mundo". Una visión del mundo que se pierde cuando muere una lengua. Siempre me he preguntado qué implica. ¿Qué es exactamente una visión del mundo? ¿Es posible compartir una visión del mundo con hablantes de lenguas distintas a las nuestras? ¿El hecho de hablar lenguas distintas necesariamente niega la posibilidad de compartir una misma visión del mundo? La frase en sí misma tiene un tono determinista que esconde muchas veces la complejidad de la relación entre mundo y lenguaje. No seré yo quien aquí dé una respuesta contundente a estas preguntas (y agregar ¿qué es el mundo? ¿cómo visionamos el mundo?) pero creo que es importante sospechar de ella. La relación entre el mundo o la realidad, lo que sea que eso sea, y una lengua en específico suele ser compleja y no necesariamente directa. ${ }^{18}$

Si habíamos comenzado con una afirmación de Montaigne, "nuestro mundo acaba de encontrar otro", concluimos con una escritora que desenmascara y pone a prueba la complejidad de la relación entre mundo y lenguaje: ¿qué es el mundo?

Muchas son las paradojas del ensayo. Una de ellas es que cuando Montaigne se refirió a ensayar, probar, pesar, experimentar, dar cuenta de la propia experiencia, estaba pensando en un libro único en su género, y nunca sospechó la enorme descendencia que habría de tener, al punto de que hoy ya se reconoce que este tipo de textos corresponde a un "cuarto género", ejercicio de lucidez que envía a la perspectiva de un autor y al mundo por él observado. Hoy algunos autores se refieren incluso a "la ensayificación de todo", en cuanto el ejercicio de entender, de dar una opinión razonada a través de un estilo del pensar y del decir, se ha expandido en nuestra sociedad. Todo nos lleva a confirmar la fuerte presencia de la literatura de ideas, de la prosa interpretativa, de la intervención crítica, del encuentro dialógico y la tensión polémica, que son distintas formas de hacer ensayo.

Hoy me preocupa la posibilidad de ver en el ensayo una forma de diálogo intelectual que abre el conocimiento a nuevas fronteras. Por una parte, el ensayo, tan ligado en una época al "soporte" del libro y la revista, ingresa hoy a los blogs y a las páginas de internet. Por otra parte, nuevos protagonistas, nuevos sectores, nuevas experiencias, exigen

18 Yásnaya Aguilar, "Sobre calabazas y chilacayotes. Lengua, palabras y visión del mundo", en Ayuujk, Este País (México), 21 de mayo de 2019. Disponible en: https://estepais.com/blogs/ayuujk-sobre-calabazas-ychilacayotes-lengua-palabras-y-vision-del-mundo/

Revista Moara, n. 56, vol. 1, ago-dez 2020 ISSN:0104-0944 
también al ensayo escrito en español un ejercicio de crítica y autocrítica para abrir a la posibilidad de que ingresen otros testimonios, otras formas de organizar el discurso, otras lenguas, otras culturas.

Para terminar, retomo las palabras con que me referí a "El ensayo: un género sin residencia fija, donde aspiro a

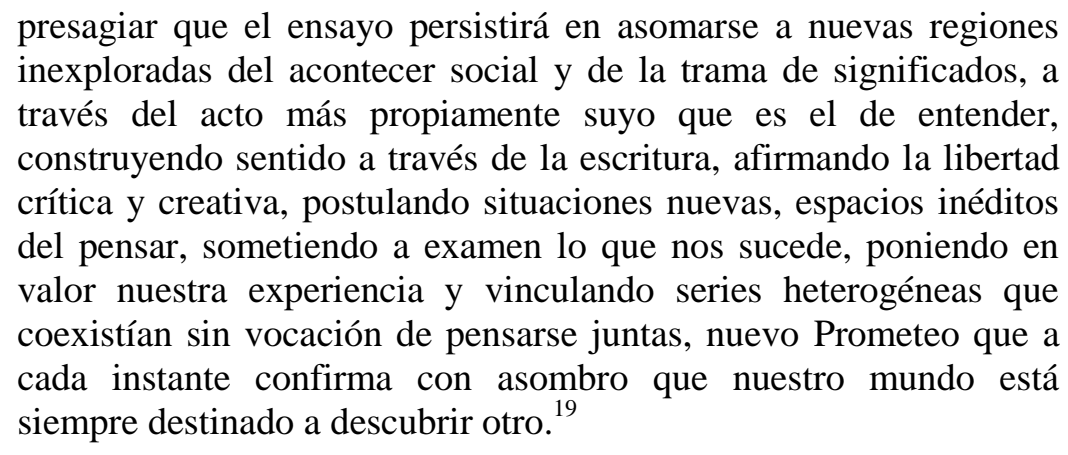

\section{BIBLIOGRAFÍA}

Aguilar Gil, Yásnaya, "Sobre calabazas y chilacayotes. Lengua, palabras y visión del mundo”, en Ayuujk, Este País (México), 21 de mayo de 2019. Disponible en:

https:/estepais.com/blogs/ayuujk-sobre-calabazas-y-chilacayotes-lengua-palabras-y-visiondel-mundo/

Arciniegas, Germán, "Nuestra América es un ensayo”, Cuadernos (París), 3 (1963), pp. 9-16.

Cruz, Sor Juana Inés de la, Respuesta a Sor Filotea (Carta Atenagórica), México: Editores Mexicanos Unidos, 2001 [1575].

Desan, Philippe (dir.), Dictionnaire de Michel de Montaigne, Paris, Honnoré Champion, Nouvelle édition revue, corrigée et augmentée, 1991.

García Márquez, Gabriel, “América Latina existe”, El País (Madrid), 23 de octubre de 2010 [1995]. Disponible en: https://elpais.com/diario/2010/10/23/babelia/1287792762_850215.html

19 Liliana Weinberg, "El ensayo: un género sin residencia fija", en Liliana Weinberg (coord.), El ensayo en diálogo, vol. II, México: CIALC, UNAM, 2017, p. 461.

Revista Moara, n. 56, vol. 1, ago-dez 2020 ISSN:0104-0944 
Henríquez Ureña, Pedro, “El descubrimiento del Nuevo Mundo en la imaginación de Europa”, Las corrientes literarias en la América Hispánica, en Obras Completas, t. X, prólogo de Juan Jacobo de Lara, traducción de Joaquín Díez-Canedo, Santo Domingo: Universidad Nacional Pedro Henríquez Ureña, 1980 [1945], pp. 43-70.

Jiménez, Blas, “Afrodominicano por elección/negro por nacimiento”, en Afrodominicano por elección/negro por nacimiento, Santo Domingo: Manatí, 2008, pp. 9-15.

Marcel, Jean, "Forme et fonction de l'essai dans la littérature espagnole", en Approches de l'essai, Anthologie, Québec, Éditions Nota bene, 2003, pp. 85-103.

Martí, José, "Nuestra América”, en Obras Completas, t. VI, La Habana: Editorial de Ciencias Sociales, 1992 [1891], pp. 15-23.

Molina, Juan Ignacio, Saggio sulla Storia Naturale del Chili, Bolonia: Stamperia di San Tommaso d'Aquino, 1782. Disponible en: https://bivaldi.gva.es/es/consulta/registro.cmd?id=6582 Montaigne, Michel de, Essais. Cronol. et introd. Alexandre Micha, 3 vols. París, Flammarion, 1962. [1580-1595].

Montoya, Pablo, "Español, lengua mía”, en Español, lengua mía y otros discursos, Medellín: Sílaba Editores, 2017, pp. 9-21.

Reyes, Alfonso, Última Tule, en Obras Completas, t. XI, México: FCE, 1960 [1920-1941], pp. 1162.

Roig, Arturo Andrés, “Educación para la integración y utopía en el pensamiento de Simón Rodríguez. Romanticismo y reforma pedagógica en América Latina”, Latinoamérica. Anuario de Estudios Latinoamericanos, núm. 15, 1982, pp. 329-366.

Weinberg, Liliana, "El ensayo: un género sin residencia fija”, en Liliana Weinberg (coord.), El ensayo en diálogo, vol. II, México: CIALC, UNAM, 2017, pp. 449-461.

Zubiate, Jean-Pierre, “Essai et poésie au XXè siècle”, en Pierre Glaudes, L'Essai. Métamorphoses d'un genre, Université de Toulouse-le-Mirail: Presses Universitaires du Mirail, 2002, pp. 382-389.

Revista Moara, n. 56, vol. 1, ago-dez 2020 ISSN:0104-0944 